\title{
Resistance to Thyroid Hormone Complicated with Type 2 Diabetes and Cardiomyopathy in a Patient with a $\operatorname{TR} \beta$ Mutation
}

\author{
Hisao Wakasaki ${ }^{1}$, Miyuki Matsumoto ${ }^{1}$, Shinya Tamaki ${ }^{1}$, Kaori Miyata ${ }^{1}$, Shohei Yamamoto ${ }^{1}$, \\ Takamasa Minaga ${ }^{1}$, Yoshitaka Hayashi ${ }^{2}$, Kenichi Komukai ${ }^{3}$, Toshio Imanishi ${ }^{3}$, \\ Hiroyuki Yamaoka ${ }^{4}$, Shohei Matsuno ${ }^{4}$, Masahiro Nishi ${ }^{4}$ and Takashi Akamizu ${ }^{4}$
}

\begin{abstract}
Resistance to thyroid hormone (RTH) is a genetic disorder characterized by reduced tissue responsiveness to thyroid hormone. We herein describe a 60 -year old man who presented with the clinical features of cardiomyopathy, diabetes mellitus and elevated thyroid hormones with unsuppressed thyroid stimulating hormone. A genetic analysis of thyroid hormone receptor (TR) revealed a missense mutation (A268D) in the TR $\beta$ gene. Clinical manifestations of RTH may be variable due to different tissue distributions of TR subtypes and different actions of mutant receptors. The current case demonstrates that patients with a $T R \beta$ mutation may have impaired his glucose metabolism and a reduced cardiac function, although patients appear clinically euthyroid.
\end{abstract}

Key words: resistance to thyroid hormone, cardiomyopathy, diabetes mellitus, thyroid hormone receptor beta

(Intern Med 55: 3295-3299, 2016)

(DOI: 10.2169/internalmedicine.55.7147)

\section{Introduction}

Resistance to thyroid hormone (RTH) is an autosomal dominant disorder characterized by variable tissue hyposensitivity to triiodothyronine (T3), with persistent elevation of serum free T3 (FT3) and free thyroxine (FT4) levels, along with inappropriately non-suppressed thyroid stimulating hormone (TSH).

This syndrome was initially identified by Refetoff and colleagues in 1967 (1). The majority of cases are associated with mutations in the thyroid hormone receptor beta (TR $\beta$ ) gene $(2,3)$. Heterozygous mutations in the TR $\beta$ gene, localized to restricted regions of the hormone-binding domain, cause a loss of receptor function. The mutant receptors are transcriptionally impaired, due to reduced ligand binding or attenuated interaction with co-activators, and inhibit wild- type TR $\beta$ and TR $\alpha$ action in a dominant-negative manner (4). Heterozygous members of a family who had only one deleted TR $\beta$ allele revealed normal clinical and laboratory findings (5). These findings suggest that a single copy of $T R \beta$ is sufficient for a normal function, and $T R \beta$ point mutations interfere with the normal functions of TR in human.

The pathogenesis of variable tissue resistance is not fully understood, but may be related to the differing tissue distributions of $T R \beta$ and $T R \alpha$ and variable dominant-negative activity of mutant receptors on different target genes.

Individuals with RTH do not generally exhibit severe symptoms of hypothyroidism, because hormone resistance is believed to be compensated by increased thyroid hormone. The classic clinical features of RTH include thyroid goiter, attention deficit disorders, delayed skeletal maturation, tachycardia, and an impaired metabolic response to thyroid

\footnotetext{
${ }^{1}$ Department of Endocrinology and Diabetology, Hidaka General Hospital, Japan, ${ }^{2}$ Department of Genetics, Research Institute of Environmental Medicine, Nagoya University, Japan, ${ }^{3}$ Department of Cardiology, Hidaka General Hospital, Japan and ${ }^{4}$ The first Department of Medicine, Wakayama Medical University, Japan

Received for publication January 18, 2016; Accepted for publication March 10, 2016

Correspondence to Dr. Hisao Wakasaki, wakasaki@wakayama-med.ac.jp
} 
Table 1. Laboratory Data on Admission.

\begin{tabular}{lclr}
\hline WBC & $5,300 / \mu \mathrm{L}$ & Albumin & $4.03 \mathrm{~g} / \mathrm{dL}$ \\
$\mathrm{Hb}$ & $13.5 \mathrm{~g} / \mathrm{dL}$ & $\mathrm{Na}$ & $136 \mathrm{mmol} / \mathrm{L}$ \\
$\mathrm{Ht}$ & $41.2 \%$ & $\mathrm{~K}$ & $4.1 \mathrm{mmol} / \mathrm{L}$ \\
$\mathrm{Plt}$ & $12.6 \times 10^{4} / \mu \mathrm{L}$ & $\mathrm{Cl}$ & $101 \mathrm{mmol} / \mathrm{L}$ \\
& & $\mathrm{Ca}$ & $8.6 \mathrm{mg} / \mathrm{dL}$ \\
& & $\mathrm{IP}$ & $3.8 \mathrm{mg} / \mathrm{dL}$ \\
U-pH & 7.5 & Creatinine & $0.84 \mathrm{mg} / \mathrm{dL}$ \\
U-protein & $(-)$ & eGFR & $72.5 \mathrm{~mL} / \mathrm{min} / 1.73 \mathrm{~m}^{2}$ \\
U-glucose & $(-)$ & BUN & $24.8 \mathrm{mg} / \mathrm{dL}$ \\
U-ketone & $(-)$ & UA & $6.3 \mathrm{mg} / \mathrm{dL}$ \\
U-ACR & $6.9 \mathrm{mg} / \mathrm{gCr}$ & CRP & $0.40 \mathrm{mg} / \mathrm{dL}$ \\
& & AST & $32 \mathrm{U} / \mathrm{L}$ \\
& & ALT & $22 \mathrm{U} / \mathrm{L}$ \\
& & $\gamma G T P$ & $206 \mathrm{U} / \mathrm{L}$ \\
& & ALP & $592 \mathrm{U} / \mathrm{L}$ \\
& & LDH & $281 \mathrm{U} / \mathrm{L}$ \\
& & CK & $252 \mathrm{U} / \mathrm{L}$ \\
& & TG & $54 \mathrm{mg} / \mathrm{dL}$ \\
& & LDL-Cholesterol & $69 \mathrm{mg} / \mathrm{dL}$ \\
& & HDL-Cholesterol & $37 \mathrm{mg} / \mathrm{dL}$ \\
\hline
\end{tabular}

ACR: Albumin Creatinine Ratio, 'U-' indicates urinary levels

hormone. Other symptoms, such as frequent ear and throat infections, hearing loss, and a decreased bone mass have been recognized (6-8).

We herein describe a RTH patient with a $T R \beta$ mutation who exhibited the symptoms of heart failure and an impaired glucose metabolism.

\section{Case Report}

A 60-year-old man was referred to our hospital because of abnormal thyroid function test results. He presented with episodic palpitations at 16 years of age, and was diagnosed with Graves' disease. After one year of treatment, he stopped visiting the hospital. He had no history of hyperactivity, learning problem or low performance. At 46 years of age, he was noted to have a high plasma glucose level (236 $\mathrm{mg} / \mathrm{dL})$ and elevated HbA1c (8.2\%). He was diagnosed with diabetes mellitus and treated with $1 \mathrm{mg}$ of glimepiride, a glucose-lowering agent. At 53 years of age, he was admitted to a hospital with symptoms of dizziness, and his electrocardiogram showed bradycardia with atrial fibrillation. The results of a thyroid function test at this time revealed that the serum level of fT4 was $3.0 \mathrm{ng} / \mathrm{dL}$. He received a permanent pacemaker and was started on anti-thyroid therapy with methimazole (MMI). Basal insulin therapy was also introduced at this time.

When he visited our hospital, his anti-thyroid antibodies were all negative. The results of his thyroid function tests after stopping MMI treatment for two months revealed that the serum levels of fT4 and TSH were $3.5 \mathrm{ng} / \mathrm{dL}$ and 3.43 $\mu \mathrm{IU} / \mathrm{mL}$, respectively, indicating syndrome of inappropriate TSH secretion (SITSH). The patient reported no thyroid disease in his family. A genetic analysis and thyroid function tests were not performed for other family members.

His physical examination revealed the following: height, $161 \mathrm{~cm}$; weight, $59 \mathrm{~kg}$ (body mass index, 22.7); pulse rate,
63 beats/min; blood pressure, 110/70 $\mathrm{mmHg}$; and body temperature, $37.3{ }^{\circ} \mathrm{C}$. The thyroid gland was normal, and there was no lid retraction. A systolic ejection murmur was detected in the cardiac apex area. No abnormal lung sound was detected. No specific findings were observed on abdominal examinations. Moderate pre-tibial pitting edema was present on bilateral legs. He had simple diabetic retinopathy and moderate peripheral neuropathy.

In laboratory tests on admission, the complete blood count was normal and, urinary albumin excretion was within the normal range. His C-reactive protein level was normal, creatinine was $0.84 \mathrm{mg} / \mathrm{dL}$ (normal range: 0.6 to $1.1 \mathrm{mg}$ / $\mathrm{dL}$ ), blood urea nitrogen (BUN) was $24.8 \mathrm{mg} / \mathrm{dL}$ (normal range: 6 to $20 \mathrm{mg} / \mathrm{dL}$ ), aspartate aminotransferase (AST) and alanine aminotransferase (ALT) were within the normal ranges, and alkaline phosphatase (ALP) was 592 U/L (normal range 104 to $338 \mathrm{U} / \mathrm{L})$. His lipid profiles were lowdensity lipoprotein (LDL)-cholesterol $69 \mathrm{mg} / \mathrm{dL}$, highdensity lipoprotein (HDL)-cholesterol $37 \mathrm{mg} / \mathrm{dL}$, and triglyceride $54 \mathrm{mg} / \mathrm{dL}$ (Table 1). His fasting plasma glucose was $114 \mathrm{mg} / \mathrm{dL}$ and $\mathrm{HbA} 1 \mathrm{c}$ was $8.1 \%$ under multiple injections of rapid-acting insulin. His FT4 level was $3.50 \mathrm{ng} / \mathrm{dL}$ (normal range: 0.70 to $1.48 \mathrm{ng} / \mathrm{dL}$ ), FT3 was $4.81 \mathrm{pg} / \mathrm{mL}$ (normal range: 1.71 to $3.71 \mathrm{pg} / \mathrm{mL}$ ), TSH was $3.43 \mu \mathrm{IU} / \mathrm{mL}$ (normal range: 0.35 to $4.94 \mu \mathrm{IU} / \mathrm{mL}$ ), anti-thyroglobulin and anti-thyroid peroxidase antibodies were negative, and antiTSH receptor antibody level was below 1.0 UI/L (normal range: 0.0 to $1.0 \mathrm{UI} / \mathrm{L}$ ). Other hormonal results were cortisol $8.7 \mu \mathrm{g} / \mathrm{dL}$ (normal range 3.7 to $19.4 \mu \mathrm{g} / \mathrm{dL}$ ), adrenocorticotropic hormone (ACTH) $63.0 \mathrm{pg} / \mathrm{mL}$ (normal range 7.2 to $63.3 \mathrm{pg} / \mathrm{mL}$ ), prolactin $20.0 \mathrm{ng} / \mathrm{mL}$ (male normal range 3.46 to $19.4 \mathrm{ng} / \mathrm{mL}$ ), luteinizing hormone $2.82 \mathrm{mIU} / \mathrm{mL}$, follicle stimulating hormone $3.5 \mathrm{mIU} / \mathrm{mL}$, insulin-like growth factor (IGF)-1 $62 \mathrm{ng} / \mathrm{mL}$ (normal range 79 to $232 \mathrm{ng} / \mathrm{mL}$ ) and brain natriuretic peptide (BNP) $2,182 \mathrm{pg} / \mathrm{mL}$ (normal range 0.0 to $18.4 \mathrm{pg} / \mathrm{mL}$ ). On a glucagon loading test, C peptide increment at 5 minutes after $1 \mathrm{mg}$ of intravenous glucagon injection was $2.75 \mathrm{ng} / \mathrm{mL}$. He also underwent thyrotropinreleasing hormone (TRH) stimulation testing. After receiving $200 \mu \mathrm{g}$ of TRH, the TSH showed a normal response (TSH at baseline, $5.23 \mu \mathrm{IU} / \mathrm{mL}$; TSH at 30 minutes, $18.20 \mu \mathrm{IU} /$ $\mathrm{mL}$; TSH at 60 minutes, $19.89 \mu \mathrm{IU} / \mathrm{mL}$; and TSH at 120 minutes, $11.59 \mu \mathrm{IU} / \mathrm{mL}$ ) (Table 2).

On chest radiography, the cardiothoracic ratio was $62 \%$ and bilateral increased lung markings were observed. The electrocardiogram showed pacing rhythm with a heart rate of $60 \mathrm{bpm}$. An echocardiogram revealed a moderately dilated left ventricular cavity with diffuse hypokinesis; left atrial diameter measured $54 \mathrm{~mm}$, end-diastolic left ventricular diameter measured $55 \mathrm{~mm}$, end-systolic left ventricular diameter measured $51 \mathrm{~mm}$, left ventricular ejection fraction was $15.1 \%$, and no valvular disease was detected. Doppler recordings of transmitral filling velocities showed an E/A wave ratio of 4.3 and deceleration time (DcT) of 114 milliseconds, indicating a restrictive filling pattern (Table 3). Coronary angiography revealed a normal coronary artery. 
Table 2. Laboratory Data and Endocrinological Test.

\begin{tabular}{lrll}
\hline FT3 & $4.81 \mathrm{pg} / \mathrm{mL}$ & $(1.71-3.71)$ \\
FT4 & $3.50 \mathrm{ng} / \mathrm{dL}$ & $(0.70-1.48)$ \\
TSH & $3.43 \mu \mathrm{IU} / \mathrm{mL}$ & $(0.35-4.94)$ \\
Tg Ab & $<10 \mathrm{IU} / \mathrm{mL}$ & $(<28)$ \\
TPO Ab & $8 \mathrm{IU} / \mathrm{mL}$ & $(<16)$ \\
TRAb & $<1.0 \mathrm{IU} / \mathrm{L}$ & $(<1.0)$ \\
TBG & $11.8 \mathrm{mg} / \mathrm{mL}$ & $(15.9-35.6)$ \\
FPG & $114 \mathrm{mg} / \mathrm{dL}$ & \\
HbA1c & $8.1 \%$ & \\
anti-GAD Ab & $<0.3 \mathrm{U} / \mathrm{mL}$ & $<1.5$ \\
Prolactin & $21.0 \mathrm{ng} / \mathrm{mL}$ & $(3.46-19.4)$ \\
GH & $1.96 \mathrm{ng} / \mathrm{mL}$ & $(<2.47)$ \\
IGF-1 & $62 \mathrm{ng} / \mathrm{mL}$ & $(79-232)$ \\
LH & $2.82 \mathrm{mIU} / \mathrm{mL}$ & $(1.7-11.2)$ \\
FSH & $3.50 \mathrm{mIU} / \mathrm{mL}$ & $(2.1-18.6)$ \\
ACTH & $63 \mathrm{pg} / \mathrm{mL}$ & $(7.2-63.3)$ \\
Cortisol & $8.7 \mu \mathrm{gg} / \mathrm{dL}$ & $(2.9-19.4)$ \\
BNP & $2,182 \mathrm{pg} / \mathrm{mL}$ & $(<18.4)$ \\
\hline
\end{tabular}

(normal value)

\begin{tabular}{|c|c|c|c|c|c|c|c|}
\hline \multicolumn{3}{|c|}{ Glucagon loading test } & \multicolumn{5}{|c|}{ TRH loading test } \\
\hline & $0 \mathrm{~min}$ & $5 \mathrm{~min}$ & & $0 \mathrm{~min}$ & $30 \mathrm{~min}$ & $60 \mathrm{~min}$ & $120 \mathrm{~min}$ \\
\hline CPR & 1.72 & 4.47 & $\mathrm{TSH}$ & 5.23 & 18.20 & 19.89 & 11.59 \\
\hline \multicolumn{3}{|c|}{$\Delta$ CPR5min. $=2.75$} & Prolactin & 11.4 & 47.5 & 39.5 & 23.5 \\
\hline
\end{tabular}

BNP: Brain Natriuretic Peptide, CPR: C Peptide Immunoreactivity, FT3: Free Triiodothyronine, FT4: Free Thyroxine, Anti-GAD Ab: Antiglutamic Acid Decarboxylase Antibody, IGF-1: Insulin Like Growth Factor-1, TBG: Thyroxine Binding Globulin, TgAb: Anti-thyroglobulin Antibody, TPO Ab: Anti-thyroid Peroxidase Antibody, TRAb: AntiTSH Receptor Antibody

\section{Wild type ttggaagccttcagcc} A268D

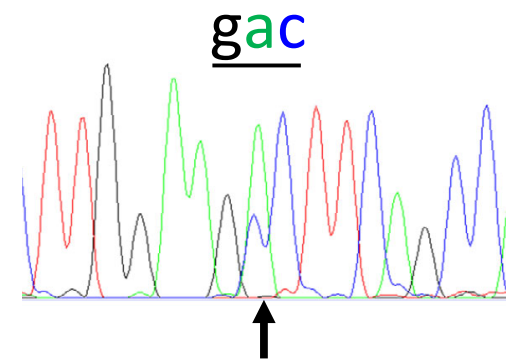

Figure. Direct sequencing analysis of TR $\beta$ gene. A missense mutation on codon 268: alanine to aspartic acid (A268D). An arrow indicates the site of a point mutation $(\uparrow)$.

Thyroid ultrasound showed normal echo texture and vascular flow. Tiny cystic areas measuring 2 to $4 \mathrm{~mm}$ were detected on both lobes. There were no significant nodules in his thyroid gland. Pituitary adenoma was not found by computed tomography. Magnetic resonance imaging was not performed because he received a pacemaker.

Written informed consent was obtained, and a genetic study was conducted. A direct sequencing analysis of the full $T R \beta$ gene identified a heterozygous, missense mutation in exon 8 , with a replacement of alanine for aspartic acid at codon 268 (A268D) (Figure).

The patient's activities of daily living (ADLs) were sufficient to allow him to be discharged. His serum TSH and fT4
Table 3. Echocardiographic Characteristics.

\begin{tabular}{lrl}
\hline LVEDD & $55 \mathrm{~mm}$ \\
LVESD & $51 \mathrm{~mm}$ \\
Ejection fraction & 15.1 & $\%$ \\
Left atrial diameter & 54 & $\mathrm{~mm}$ \\
Left atrial volume & 95.7 & $\mathrm{~mL}$ \\
E/A ratio & 4.3 & \\
DcT & 114 & $\mathrm{msec}$ \\
LVPW & $7 \mathrm{~mm}$ \\
IVS & $6.2 \mathrm{~mm}$ \\
\hline E/A: Early Left Ventricular Filling \\
Velocity/late Left Ventricular Filling \\
Velocity, DcT: E Wave Deceleration \\
Time, IVS: Interventricular Septal \\
Thickness, LVEDD: Left Ventricular \\
End-diastolic Diameter, LVESD: Left \\
Ventricular End-systolic Diameter, \\
LVPW: Left Ventricular Posterior \\
Wall Thickness
\end{tabular}

levels were stable without anti-thyroid agents or thyroid hormone replacement. Glycemic control was performed using a dipeptidyl peptidase-4 (DPP-4) inhibitor and multiple-dosage insulin injections (rapid acting insulin analogue: 20 units/ day). A recent laboratory result of his HbA1c level was $8.1 \%$, which indicates poor glycemic control. He has been treated for heart failure with a $\beta$-blocker, spironolactone, furosemide and a vasopressin receptor antagonist. He is comfortable at rest, but moderate physical activity currently results in fatigue and shortness of breath.

\section{Discussion}

\section{Reduced sensitivity to thyroid hormone}

Thyroid hormones have diverse actions, which include regulation of skeletal growth; maturation of the central nervous system, cardiac and gastrointestinal function; and energy homeostasis. These actions are mediated by thyroid hormone receptors. The receptors are encoded by two genes (TR $\alpha$ and TR $\beta$ ), each of which undergoes alternate splicing to generate receptor subtypes (TR $\alpha 1, T R \beta 1$ and $T R \beta 2$ ) with differing tissue distributions. TR $\alpha 1$ is the predominant subtype in the bone, gastrointestinal tract, cardiac and skeletal muscle, and the central nervous system; TR $\beta 1$ is most abundant in the liver and kidney; and TR $\beta 2$ is discretely expressed in the hypothalamus, pituitary, cochlea, and retina (9).

RTH is characterized by reduced responsiveness of target tissues to thyroid hormone, and $85 \%$ of patients with RTH have a TR $\beta$ mutation (10). Thus, RTH has become synonymous with dysfunction of the TR $\beta$ gene. Novel mutations presenting reduced sensitivity to thyroid hormone were reported on monocarboxylate transporter8 (MCT8) and selenocysteine insertion sequence-binding protein (SECISBP 2) $(11,12)$. Reduced sensitivity to thyroid hormone syndrome (RSTH) has been proposed to denote genetically de- 
termined reduced effectiveness of the hormone in this context $(2,10)$.

In this case report, the patient presented with RSTH associated with a TR $\beta$ mutation. Judging from his clinical course and the laboratory results, the initial diagnosis of Graves' disease was incorrect. The patient's mutation, A268D, was reported to have reduced ligand-binding affinities and inhibit the wild-type TR $\beta$ action in a dominant-negative manner (13). To the best of our knowledge, this is the first case report that evaluated glucose tolerance and the cardiac function in a patients with a $T R \beta(A 268 D)$ mutation.

\section{Cardiovascular involvement in thyroid hormone re- sistance}

Thyroid hormones have significant effects on the cardiovascular system through multiple mechanisms. Patients with hypothyroidism have decreased cardiac contractility and cardiac output. On the other hand, patients with hyperthyroidism have increased cardiac contractility and cardiac output, with an increased left ventricular mass. However, patients with severe, sustained hyperthyroidism may have poor cardiac contractility, low cardiac output, and symptoms of congestive heart failure associated with dilated cardiomyopathy (14-16). It is reported that approximately $6 \%$ of thyrotoxic patients develop heart failure and less than $1 \%$ develop dilated cardiomyopathy with an impaired left ventricular systolic function (17). The persistence of hyperthyroidism may cause hypertrophic cardiomyopathy and progress to a dilated cardiomyopathy-like state. Patients with atrial fibrillation may develop cardiac dilatation and irreversible damage of cardiomyocytes, progressing to congestive heart failure.

The heart may be less resistant than other organs because $\mathrm{TR} \alpha$ is more predominant than TR $\beta$. Mutations in TR $\beta$ are associated with pituitary and liver resistance, whereas the tachycardia observed in patients with RTH may reflect cardiac sensitivity to thyroid hormone through intact $\operatorname{TR} \alpha$ receptors.

A study using dominant-negative mutant TR $\beta$ transgenic mice showed cardiac abnormalities similar to those present in hypothyroid animals, such as prolonged QRS in the electrocardiogram, reduced left ventricular (LV)-developed pressure, and reduced $\mathrm{dp} / \mathrm{dt}$, which is a measure of the rate of change of contraction and relaxation indicating LV dysfunction (18). These data in mice hearts indicated that a dominant-negative TR $\beta$ mutant can oppose and overwhelm the effects of the normally predominant TR $\alpha 1$.

Kahaly et al. investigated 41 patients with RTH by echocardiography and reported cardiac features of a higher heart rate and shorter diastolic relaxation in RTH subjects (19). For many parameters, RTH patients had values that were between hyperthyroidism and healthy euthyroid control. From these findings, the authors concluded that an incomplete cardiac response to thyroid hormone is present in RTH.

The results of Doppler echocardiography and coronary angiography for our case revealed a decreased left ventricu- lar systolic function and impaired diastolic function with normal coronary artery. Although the molecular mechanism was not tested, these results suggested that the cardiac functions of the current patient exhibited characteristics of dilated cardiomyopathy. The clinical presentation of RTH is heterogeneous and highly variable. It is possible that the cardiac manifestations in the current case may thus not be typical.

\section{Glucose metabolism and thyroid hormone resis- tance}

Thyroid hormones have a large impact on glucose metabolism. In murine pancreatic $\beta$-cells, thyroid hormone rapidly induces Akt activation via TR $\beta 1$, with a non-genomic mechanism (20). Although the physiological function is not understood, TR $\alpha 1$ is mainly expressed in $\alpha$-cells (21). Thyrotoxic subjects frequently show impaired glucose tolerance. This is a result of increased glucose turnover with increased glucose absorption through the gastro-intestinal tract, postabsorptive hyperglycemia, and elevated hepatic glucose output, with elevated pro-insulin levels and elevated free fatty acid concentrations (22). Thyroid hormone effects can be either insulin agonistic in muscle or antagonistic in the liver. In hyperthyroidism, dysregulation of this balance leads to glucose intolerance, mainly due to hepatic insulin resistance. On the other hand, in hypothyroidism, a previous study reported the glucose uptake in muscle and adipose tissue to be resistant to insulin partly due to a decreased blood flow in these tissues (23).

The influence of impaired TR signaling on the glucose metabolism was experimentally investigated in a mouse model. Mice bearing the homozygous mutation $\Delta 337 \mathrm{~T}$ on the TR $\beta$ gene $\left(T R \beta^{\Delta 337 T / \Delta 337 T}\right)$ are leaner and exhibit impaired hepatic glucose production, reduced gluconeogenesis and lower glycogen deposit (24). Heterozygous mice $\left(\mathrm{TR} \beta^{\mathrm{wT} / \Delta 337 \mathrm{~T}}\right)$ exhibited a similarly glucose metabolism to wild-type mice in this study. The majority of patients with RTH are heterozygous for $T R \beta$ mutations. The discrepancy between transgenic models and patients may be due to species differences, various mutations and/or the heterogeneous distribution of TR subtypes.

Mitchell et al. showed that RTH subjects exhibited insulin resistance (25). In this study, RTH patients undergoing oral glucose tolerant testing had significantly lower insulin sensitivity indices and significantly higher homeostasis model assessment-insulin resistance (HOMA-IR) than controls, indicating the presence of insulin resistance. Moreover, a recent case report of a RTH patient complicated with diabetes suggested the potential interactions between diabetes mellitus and thyroid hormone resistance (26). We did not perform the glucose clamp technique or minimal model approach in order to quantify insulin resistance in this patient. However, we speculate that our patient exhibited insulin resistance, because his basal and glucagon stimulated insulin secretion were not impaired. These findings may support the possibility that glucose intolerance is present in patients with thy- 
roid hormone resistance. Type 2 diabetes is a major common disease and cardiomyopathy is caused by many conditions such as hypertension, coronary ischemia, diabetes, alcohol drinking, metabolic diseases, viral infections, pregnancy, sarcoidosis, amyloidosis, and toxins. Although these two diseases can incidentally co-exist in RTH patients, a further accumulation of clinical data may be necessary to determine whether diabetes mellitus and cardiomyopathy are induced by a $T R \beta$ mutation in humans.

In conclusion, resistance to thyroid hormone may be associated with cardiomyopathy and diabetes mellitus. Our findings suggested that the cardiac function and glucose metabolism should be investigated in all RTH patients.

The authors state that they have no Conflict of Interest (COI).

\section{References}

1. Refetoff S, DeWind LT, DeGroot LJ. Familial syndrome combining deafmutism, stippled epiphyses, goiter, and abnormally high PBI: possible target organ refractoriness to thyroid hormone. J Clin Endocrinol Metab 27: 279-294, 1967.

2. Refetoff S. Resistance to thyroid hormone: one of several defects causing reduced sensitivity to thyroid hormone. Nat Clin Pract Endocrinol Metab 4: 1, 2008.

3. Dumitrescu AM, Refetoff S. The syndromes of reduced sensitivity to thyroid hormone. Biochim Biophys Acta 1830: 3987-4003, 2013.

4. Sakurai A, Miyamoto T, Refetoff S, DeGroot LJ. Dominant negative transcriptional regulation by a mutant thyroid hormone receptor- $\beta$ in a family with generalized thyroid hormone resistance. Mol Endocrinol 4: 1988-1994, 1990.

5. Takeda K, Sakurai A, Degroot LJ, ad Refetoff S. Recessive inheritance of thyroid hormone resistance caused by complete deletion of the protein-coding region of the thyroid hormone receptor-beta gene. J Clin Endocrinol Metab 74: 49-55, 1992.

6. Refetoff S, Weiss RE, Usala SJ. The syndrome of resistance to thyroid hormone. Endocr Rev 14: 348-399, 1993.

7. Benichou J, Hauser P, Wiggs E, Weintraub BD. Genetic and clinical features of 42 kindreds with resistance to thyroid hormone. The National Institute of Health prospective study. Ann Intern Med 123: 572-583, 1995.

8. Dumitrescu AM, Refetoff S. Impaired Sensitivity to Thyroid Hormone: Defects of Transport, Metabolism and Action. In: Endotext (http://www.thyroidmanager.org). DeGroot LJ, Beck-Peccoz P, Chrousos G, et al, Eds. 2015.

9. Lazar MA. Thyroid hormone receptors. Multiple forms, multiple possibilities. Endocr Rev 14: 184-193, 1993.

10. Refetoff S, Dumitrescu AM. Syndromes of reduced sensitivity to thyroid hormone: genetic defects in hormone receptors, cell transporters and deiodination. Best Pract Res Clin Endocrinol Metab
21: 277-305, 2007.

11. Visser WE, Friesema EC, Visser TJ. Minireview: thyroid hormone transporters: the knowns and the unknowns. Mol Endocrinol 25: 1-14, 2011.

12. Dumitrescu AM, Liao $X H$, Abdullah MS, et al. Mutations in SECISBP2 result in abnormal thyroid hormone metabolism. Nat Genet 37: 1247-1252, 2005.

13. Collingwood TN, Wagner R, Matthews $\mathrm{CH}$, et al. A role for helix 3 of the TR $\beta$ ligand-binding domain in coactivator recruitment identified by characterization of a third cluster of mutations in resistance to thyroid hormone. The EMBO Journal 17: 4760-4770, 1998.

14. Klein I, Ojamaa K. Thyroid hormone and the cardiovascular system. N Engl J Med 344: 501-509, 2001.

15. Watanabe E, Ohsawa H, Noike H, et al. Dilated cardiomyopathy associated with hyperthyroidism. Intern Med 34: 762-767, 1995.

16. Biondi B, Kahaly GJ. Cardiovascular involvement in patients with different causes of hyperthyroidism. Nat Rev Endocrinol 6: 431443, 2010.

17. Dahl P, Danzi S, Klein I. Thyrotoxic cardiac disease. Curr Heart Fail Rep 5: 170-176, 2008.

18. Gloss B, Sayen MR. Altered cardiac phenotype in transgenic mice carrying the delta337 threonine thyroid hormone receptor beta mutant derived from the S family. Endocrinology 140: 897-902, 1999.

19. Kahaly GJ, Matthews CH, Mohr-Kahaly S, Richards CA, Chatterjee VK. Cardiac involvement in thyroid hormone resistance. J Clin Endocrinol Metab 87: 204-212, 2002.

20. Verga Falzacappa C, Petrucci E, Patriarca V, et al. Thyroid hormone receptor TRbetal mediates Akt activation by T3 in pancreatic beta cells. J Mol Endocrinol 38 (1-2): 221-233, 2007.

21. Zinke A, Schmoll D, Zachmann M, et al. Expression of thyroid hormone receptor isoform alphal in pancreatic islets. Exp Clin Endocrinol Diabetes 111: 198-202, 2003.

22. Brenta G. Why can insulin resistance be a natural consequence of thyroid dysfunction? J Thyroid Research 152850: 1-9, 2011.

23. Dimitriadis G, Mitrou P, Lambadiari V, et al. Insulin action in adipose tissue and muscle in hypothyroidism. J Clin Endocrinol Metabolism 91: 4930-4937, 2006.

24. Santiago LA, Santiago DA, Faustino LC, et al. The $\Delta 337 \mathrm{~T}$ mutation on the TR $\beta$ causes alterations in growth, adiposity, and hepatic glucose homeostasis in mice. J Endocrinol 211: 39-46, 2011.

25. Mitchell CS, Savage DB, Dufour S, et al. Resistance to thyroid hormone is associated with raised energy expenditure, muscle mitochondrial uncoupling, and hyperphagia. J Clin Invest 120: 13451354, 2010.

26. Stagi S, Manoni C, Cirello V, et al. Diabetes mellitus in a girl with thyroid hormone resistance syndrome: a little recognized interaction between the two diseases. Hormones 13: 561-567, 2014.

The Internal Medicine is an Open Access article distributed under the Creative Commons Attribution-NonCommercial-NoDerivatives 4.0 International License. To view the details of this license, please visit (https://creativecommons.org/licenses/ by-nc-nd/4.0/).

(C) 2016 The Japanese Society of Internal Medicine http://www.naika.or.jp/imonline/index.html 